\title{
Cultural Struggle and a Drama Project
}

\author{
Micheál Mac Giolla Ghunna \\ H Block 7, Long Kesh
}

\section{Bobby Sands once wrote:}

The jails are engineered to crush the political identity of the captured republican prisoner; to crush his/her spirit and to transform him/her into a systemised answering machine with a large criminal tag stamped by oppression upon his/her back, to be duly released onto the street, politically cured, politically barren, and permanently broken in spirit.

Republican prisoners have always steadfastly resisted this strategy, through strength of spirit and power of mind. The writings of Sands, the existence of the magazine The Captive Voice/An Glór Gafa (The Voice of Irish Republican Prisoners of War) and the activities of the republican community in jail bear eloquent testimony to this fact. The recent drama project in the H Blocks, leading to the creation of the play, The Crime of Castlereagh, is yet another illustration of the cultural resilience of republican prisoners. But there is far more to it than merely an act of resistance.

It has become almost a defining feature of political prisoners throughout the world that they engage in cultural struggle. They write, compose poetry, sing and play music, paint and carve. They utilise every form of self expression. They do so not merely because they are talented thoughtful individuals (one of the reasons leading to their imprisonment), but because they wish to give voice to the pain of their people and articulate the need for radical change to end this pain. Indeed Edward Said, the Palestinian academic, has termed this the role of the intellectual in society. Similarly the recently executed Ken Saro Wiwa described his role thus:

For a Nigerian writer in my position ... literature has to be combative ... What is of interest to me is that my art should be able to alter the lives of a large number of people, of a whole community, of the entire country.... It is serious, it is politics, it is economics, it's everything. And art in that instance becomes so meaningful ... .

Moreover the Italian Marxist, Antonio Gramsci, in his own Prison Notebooks, argues that cultural struggle is central to political change, as it concerns the creation of alternative social meanings and values which challenge the dominant ideology of the ruling class. In other words, cultural struggle is about raising the political awareness of the mass of the population, exposing the apologists for injustice and inequality, and creating an alternative set of values and different perspectives of the world.

Irish republicans have al ways numbered among their ranks a high proportion of writers, poets, musicians, and artists, many of whom endured imprisonment 
Journal of Prisoners on Prisons, Vol. 7, No. 1, 1996.

and used those years to further their cultural activities. For others, the experience of imprisonment acted as a catalyst for their creative talents. This is particularly true of the present phase of the struggle. The dominant image is of a blanket clad Bobby Sands scribbling his poems, songs, and stories on a piece of toilet paper in a freezing and filthy cell. But others were similarly engaged in this cultural struggle. After the blanket protest, republican prisoners in Long Kesh made a sustained effort to put in place a programme of communal education based on the principles of Paulo Freire's Pedagogy of the Oppressed. This laid the foundation for a wide range of cultural activity from Irish language classes, poetry workshops, art and craftwork, playwriting and acting, music and song, and of course, the magazine, An Glor Gafa.

The Irish language activities are a classic example of the success of cultural struggle by prisoners having a wider impact on the struggle for political change. While Irish language groups had worked hard and with some success for many years to maintain and develop the language and Irish culture in general, that is to take and maintain control of our capacity to develop our own social meanings, the influx of released political prisoners into local nationalist communities in the 1980s provided a fresh impetus for this struggle. These were committed activists who had learned both Irish and the importance of cultural struggle in jail; and who now organised language classes and campaigns for cultural rights in their local areas, helped to set up and maintain Irish schools, and got involved in a wide range of other cultural activities. The effect was to increase the community's confidence in their own ability to define and express their own interests and aspirations independently. It added to the vibrancy and dynamism of a community that could sustain a broad political, social, and economic struggle over many years. This interaction of cultural and other aspects of struggle is clearly illustrated in initiatives like the West Belfast Community Festival.

It is in this context of an historical cultural struggle in the jails and its interaction with community struggle outside that the recent drama project in Long Kesh took place. A small group of POWs came together, along with Tom Magill of the Community Arts Forum, to adapt for stage performance a trilogy of poems by Bobby Sands. Such a project offered us individual benefits such as skills development and confidence building. However, while personal development is always encouraged by the republican community in Long Kesh, it was by no means our only or even our main motivation. Rather it was a collective and conscious political act on our part to push forward the cultural struggle. In part, this is a continuation of the long history of jail cultural struggle; and the conditions that made the project possible are a result of the sacrifices and planning of those POWs who went before us. However, it is also part of what we see as the wider role of the artist: to articulate the experiences, hopes, and desires of their people. In this particular case, we wanted to tell the story of political imprisonment. 
It is unashamedly a republican prisoners' version of that story, focusing on the physical and psychological torture of Castlereagh, the farcical pseudo-legal imprimatur of a Diplock court, and the brutalisation of prisoners during the blanket protest in the $\mathrm{H}$ Blocks. It also tells of the hidden reserves of strength within an ordinary man to resist torture, corrupt courts, and prison brutality; and of the comradeship that ultimately defeated the criminalisation policy of the British government. However, it is not a narrow, localised account of the experiences of a political prisoner. The story could easily be set in any part of the world, for it contains universal themes and experiences of imprisonment fear, isolation, loss of family, and physical pain as well as resistance, principles, stubbornness, comradeship, and courage. There are, of course, other stories to be told - even the screws' story, and the psychological impact of the situation on them. But that is not our concern here.

The type of theatre we chose for telling the prisoners' story is also significant. Using the poetry of Bobby Sands, we organised the play on a collective basis, creating, producing, and directing as a group. In other words, rather than performing the work of someone else, we retained control and ownership of our own images, actions, and meanings. The style was surreal; thus, we created our own world with its own rules and deeper truth, rather than conforming to naturalistic conventions and the dominant version of superficial reality 'as seen on TV.' For example, which image is the truer one, the Diplock judge as a distinguished man in a red cloak, or as a pig snorting contemptuously at justice? It was also minimalist theatre; that is, we used a minimum of props. This meant that the audience had to use their imaginations and engage actively with us, instead of being the passive receptacles for our images. In fact, we were employing the principles of Augusto Boale and his 'theatre of the oppressed' principles that run parallel to those of Paulo Freire and his 'pedagogy of the oppressed' that was used by republican prisoners in the early 1980 s to lay the foundations for the educational and cultural basis of our prison community. Thus, the cultural struggle in the H Blocks had come full circle; the pedagogy of the oppressed had prepared the ground for the theatre of the oppressed. Similarly, the struggle of Bobby Sands and his comrades had now achieved the jail conditions and the cultural framework for a new generation of republican prisoners to take the struggle a stage further poignantly illustrated by translating the poetry of the Blanket protest into the drama of today's H Blocks.

The latest drama project must therefore be seen as a continuation of the long history of cultural struggle in the jails. And it was appropriate that the finished play should be performed in conjunction with the West Belfast Community Festival, yet again illustrating the interaction of jail and community struggle. This struggle will continue, as we attempt to take control of our own social meanings and values, express our experiences and those of our people, and articulate the need for radical change in Irish politics and society. It is up to all of us to participate in this cultural aspect of the wider struggle. 